Malayan Meteorological Service, Singapore; H. W. Hockin (inspector of mines, Federation of Malaya), senior research officer, Department of Mines, Federation of Malaya; P. T. Nelson, agricultural officer, Nigeria; Mrs. W. M. H. Sesseler, government chemist, Gold Coast ; N. V. Williams, fisheries officer, Nigeria; A. J. T. Bayles, assistant conservator of forests, North Borneo ; G. J. Journeaux, assistant conservator of forests, Nyasaland; B. P. Singh, assistant conservator of forests, British Honduras; C. K. Burton and J. H. Duncan, geologists, Federation of Malaya; O. von Knorring, chemist, Geological Survey, Federation of Malaya; A. F. Trendall and J. Walsh, geologists, Uganda; W. G. C. Bearcroft, medical research officer, West Africa Virus Research Institute, Nigeria; A. R. Jenkins, senior scientific officer, East African Tsetse and Trypanosomiasis Research and Reclamation Organization, East Africa High Commission; B. A. Mitchell, scientific officer, Federation of Malaya; T. Owens, veterinary officer, Northern Region, Nigeria ; W. G. C. Parker, veterinary officer, Somaliland Protectorate.

\section{Electromagnetic Wave Theory: Symposium in Ann Arbor, Michigan}

AN international symposium on electromagnetic wave theory, sponsored by Commission. VI of the International Scientific Radio Union and the University of Michigan, will be held in Ann Arbor at the University of Michigan during June 20-25. Five topics will be considered: propagation in doubly refracting media in wave guides (for example, ferrites); boundary-value problems of diffraction and scattering theory; work in antenna theory of fundamental importance ; forward scattering; and multiple scattering (that is, of light by colloidal particles). Developments at millimetre wave-lengths will be particularly considered. Anyone wishing to read a paper should submit by March 31 an abstract of not more than two hundred words to the chairman of the symposium, K. M. Siegel, Willow Run Research Center, University of Michigan, Ypsilanti, Michigan. Further information on all other points can be obtained from J. W. Crispin, jun., at the University of Michigan, Ann Arbor, Michigan.

\section{The Night Sky in January}

Full moon occurs on Jan. 8d. 12h. 44m., U.T., and new moon on Jan. 24d. 01h. $06 \mathrm{~m}$. The following conjunctions with the moon take place: Jan. 9d. 03h., Jupiter $2^{\circ}$ N.; Jan. 18d. 03h., Saturn $6^{\circ}$ N. ; Jan. 20d. 0h., Venus $6^{\circ}$ N.; Jan. 25d. 16h., Mercury $5^{\circ}$ S.; Jan. 29d. 05h., Mars $6^{\circ} \mathrm{S}$. In addition to these conjunctions with the moon, Jupiter is in conjunction with Pollux on Jan. 24d. 21h., Jupiter $6 \cdot 3^{\circ}$ S. Mercury sets an hour after the sun on January 15 and $1 \mathrm{~h} .40 \mathrm{~m}$. after sunset on January 31 , but is too close to the sun in both cases to be favourably seen. Venus is a morning object, its times of rising being about $4 \mathrm{~h} .20 \mathrm{~m}$. up to the middle of the month and $4 \mathrm{~h} .45 \mathrm{~m}$. at the end of the month. Its stellar magnitude varies from $-4 \cdot 3$ to -4 and the visible portion of the illuminated disk from $0 \cdot 348$ to $0 \cdot 528$. Mars sets about $22 \mathrm{~h}$. $25 \mathrm{~m}$. throughout the month, and, as its declination increases from $-5^{\circ}$ to nearly $5^{\circ}$, it is becoming better situated for observation in the northern hemisphere. It is not very close to any bright star, but its eastward movement from Aquarius into Pisces is obvious during the month. Jupiter, which rises early in the afternoon (at 15h. on January 31 ), is visible throughout the night and morning hours, stellar magnitude $\mathbf{- 2 \cdot 2}$. Its westward movement in Gemini as it approaches $\delta$ Geminorum is easily seen. Saturn is a morning object, rising at $3 \mathrm{~h} .45 \mathrm{~m}$., $2 \mathrm{~h} .55 \mathrm{~m}$. and $2 \mathrm{~h}$. on January 1,15 and 31 , respectively. Its declination is about $16^{\circ} \mathrm{S}$., and it does not attain a great altitude in the British Isles; its apparent eastward movement towards $\gamma$ Libræ continues until the beginning of March. Occultations of stars brighter than magnitude 6 are as follows, observations being made at Greenwich :

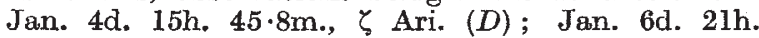
$04 \cdot 9 \mathrm{~m} ., 121$ Tau. $(D)$; Jan. 27d. 18h. 46.0m., $*$ Psc. $(D)$, where $D$ refers to disappearance. The earth reaches perihelion on January 4, its distance from the sun being then a little less than $91 \frac{1}{2}$ million miles. The Quadrantids meteors attain their maximum on January 3.

\section{Announcements}

Dr. S. J. Folley, head of the Physiology Department, National Institute for Research in Dairying, Shinfield, has been elected a corresponding member of the Société de Biologie of Paris.

Dr. T. RoBertson, assistant director (England and Wales) of the Geological Survey and Museum since 1949, is to retire on March 31 after thirtyeight years with the Survey. He will be succeeded by Dr. F. M. Trotter, who is at present district geologist in charge of the Manchester office of the Geological Survey; and Mr. J. V. Stephens will become district geologist at Manchester.

MR. J. I AMB, director of the Tea Research Institute, Ceylon, has been appointed director of the West African Cocoa Research Institute, in succession to Mr. J. West, who has retired. Mr. Lamb is taking up his new post in the latter part of 1955.

The Society for Psychical Research is offering a prize of $£ 50$ for an essay, preferably not exceeding three thousand words, on any topic relevant to the work of the Society. Entries close on June 30. Further information can be obtained from the Secretary, Society for Psychical Research, 31 Tavistock Square, London, W.C.I.

THE Population Council, Inc., of New York, is offering further fellowships for advanced training in the study of population at the predoctoral and postdoctoral levels. Fellowships will be available for study in universities in the United States and elsewhere for the academic year 1955-56, preference being given to qualified applicants from countries other than the United States and Europe. The basic stipend of 2,500 dollars per annum may be increased by allowances for travel, dependants, etc. Application forms (to be returned by March 1) and further information can be obtained from the Population Council, Inc., 230 Park Avenue, New York 17, New York.

THE Exhibition of Israeli Scientific Papers at the Israeli Consulate, 18 Manchester Square, London, W.1, which was to have closed on December 22 will remain open until January 7.

THe Wellcome Historical Medical Museum, which for the past seven years has been carrying on its activities at 28 Portman Square, London, W.1, has now removed to the Wellcome Research Institution at 183-193 Euston Road, N.W.1. Exhibitions dealing with primitive medicine and with child-welfare through the ages are open to the public in the new premises (Monday to Friday, 10 a.m.-5 p.m.). 